\title{
Ecogeographic variability and genetic diversity associated with seed albumins, globulins and prolamins patterns in Vicia taxa from Algeria
}

\author{
Sakina Bechkri", Imane Medoukali and Douadi Khelifi
}

\begin{abstract}
Genetic variability was studied in 78 populations of locally collected Vicia L. taxa for seed albumins, globulins and prolamins patterns by sodium dodecyl sulfate polyacrylamide gel electrophoresis (SDS-PAGE) along with an ecogeographic characterization of sites investigated. 131, 119 and 98 bands were respectively used for albumin, globulin and prolamin cluster analysis. Dendrograms based on the Jaccard index and the UPGMA method were generated and the degree of genetic diversity between and within taxa was evaluated. Five clusters were generated from albumins, six from globulins and four from prolamins patterns. The results reflect the great diversity of storage proteins and a high correlation was obtained between the three studied fractions. Several accessions present specific bands which could be used as a discriminatory marker both on intra and interspecific levels. No clear relationships were seen between the groups according to their geographical origin. Data obtained from ecogeographic investigation can be used for future collecting missions.
\end{abstract}

Keywords: Vicia L., Ecogeography, Electrophoresis, Albumins, Globulins, Prolamins

\section{Background}

The genus Vicia belongs to the Legumes, family Leguminosae which is considered one of the largest families of flowering plants and represents tremendous morphological, ecological and genetic diversity. Vicia L. comprises about 210 species widely distributed along Europe, Asia and the American regions (Hanelt and Mettin 1989). In Algeria, there are 26 species belonging to three series (Quézel and Santa 1962). The genus Vicia has the capacity to fix atmospheric nitrogen (Nemecek et al. 2008). Vetch seeds contain more than $20 \%$ crude protein and relatively high amount of lysine, leucine, arginine, phenylalanine and tyrosine (Darre et al. 1998). Maxted (1993) pointed out that there had been 20 major classifications of the group since Linnaeus. Kupicha (1976) has subdivided

\footnotetext{
*Correspondence: s.bechkri@gmail.com

Laboratoire de Génétique Biochimie et Biotechnologies Végétales,

Faculté des sciences de la nature et de la vie, Université Frères MENTOURI, 25000 Constantine, Algeria
}

the genus into two subgenera (Vicilla, Vicia) which have been further subdivided into 17 and 5 sections, respectively. The subgenus Vicia sensu Maxted (1993) contains 9 sections including sections Vicia, Hypechusa and Narbonensis. Section Cracca sensu Kupicha (1976) belongs to subgenus Vicilla. Morphological approach is rather difficult to estimate the all genetic diversity in the genus (Haider and El-Shanshoury 2000). Seed proteins are physiologically stable and easy to manipulate (Ladizinsky and Hymowitz 1979). Considerable insight has been drained as to their structure and synthesis during seed development and to their role as storage proteins (Higgins 1984). Electrophoretic analysis of seed storage proteins was used in testing genetic associations in Vicia at generic, specific and intraspecific levels, along with morphological characterization (Ladizinsky and Hymowitz 1979; Mirali et al. 2007; Hameed et al. 2009; Emre et al. 2010). The use of gel electrophoresis of seed protein in phylogeny is supported by the fact that mature seeds possess the same protein components unchanged with age 
or environmental stress, and thus provide valid evidence for genetic relatedness (Crawford 1990). Potokina et al. (2003) and Mirali et al. (2007) suggested that comparison of electrophoregrams of seed proteins is useful to assess relationships among Vicia taxa.

The objective of the present study was to investigate intra and interspecific variations in 11 taxa belonging to sections Vicia, Hypechusa, Narbonensis and Cracca by SDS-PAGE of seed albumins, globulins and prolamins to test the technique for vetches identification and to clarify the genetic diversity among Vicia taxa collected from different regions of the country along with an ecogeographic characterization of sites investigated as no studies have previously been reported on electrophoretic separation of the storage proteins of the given 11 Vicia taxa from Algeria.

\section{Methods}

\section{Plant material and taxa identification}

Object of the study were 78 accessions representing 4 taxa of Sect. Vicia, 2 taxa of Sect. Hypechusa, 1 taxon of Sect. Narbonensis and 4 taxa of Sect. Cracca. Pods were randomly collected from various bioclimatic conditions of Algeria (Fig. 1). The dry seeds were stored into separate sealed paper bags at room temperature until their utilization. Informations of the investigated accessions are given in Table 1. Taxonomic identification of accessions was verified by the morphology of plants grown from seeds in a greenhouse of the laboratory of genetics, biochemistry and plants biotechnologies of Faculty of
Biology in Constantine University (eastern Algeria). Taxa identification was undertaken using the key of Quézel and Santa (1962).

\section{Protein sequential extraction based on solubility}

The sequential extraction was undertaken according to Freitas et al. (2000) and Riberio et al. (2004) modified. Seeds were grinded to fine powder after seed coats were removed. $10 \mathrm{mg}$ of the resulting flour was defatted with $\mathrm{n}$-hexane $(340 \mu \mathrm{l} / 10 \mathrm{mg})$ for $1 / 4 \mathrm{~h}$ with agitation, decanted and dried in stove $\left(37^{\circ} \mathrm{C}\right)$. Albumins were extracted with water (adjusted to $\mathrm{pH} 8.0$ ) containing $10 \mathrm{mM} \mathrm{CaCl}_{2}$ and $10 \mathrm{mM} \mathrm{MgCl}{ }_{2}(340 \mu \mathrm{l} / 10 \mathrm{mg})$ for $1 / 2 \mathrm{~h}$. One $\mathrm{mM}$ phenylmethylsulphonyl fluoride (PMSF) was added to the extraction buffer. The content was centrifuged for $20 \mathrm{~min}$. at $14,000 \mathrm{rpm}\left(4{ }^{\circ} \mathrm{C}\right)$. The supernatant was recovered and the albumins were precipitated by acetone $(561 \mathrm{~g} / \mathrm{l})$. Globulins were extracted by $0.1 \mathrm{M}$ Tris- $\mathrm{HCl}$ buffer, $\mathrm{pH} 7.5-8$, containing $10 \%(\mathrm{w} / \mathrm{v}) \mathrm{NaCl}$, $10 \mathrm{mM}$ ethylenediaminetetraacetic acid (EDTA) and $10 \mathrm{mM}$ ethyleneglycol bis (b-aminoethyl ether)-N, N, N0, N0-tetraacetic acid (EGTA) (340 $\mu \mathrm{l} / 10 \mathrm{mg}$ of flour) for $1 / 2$ h. $1 \mathrm{mM}$ phenylmethylsulphonyl fluoride (PMSF) was used to extraction buffer. The solution was centrifuged for $20 \mathrm{~min}$. at $14,000 \mathrm{rpm}\left(4^{\circ} \mathrm{C}\right)$. Globulins were precipitated by acetone $(561 \mathrm{~g} / \mathrm{l})$. Prolamins were extracted by $75 \%$ ethanol $(50 \mu \mathrm{l} / 10 \mathrm{mg})$ for $20 \mathrm{~min}$. with agitation at $4{ }^{\circ} \mathrm{C}$. The prolamin-containing solution was centrifuged for $15 \mathrm{~min}$. at $14,000 \mathrm{rpm}\left(4^{\circ} \mathrm{C}\right)$ and the prolamin were precipitated by acetone $(500 \mu \mathrm{l})$.

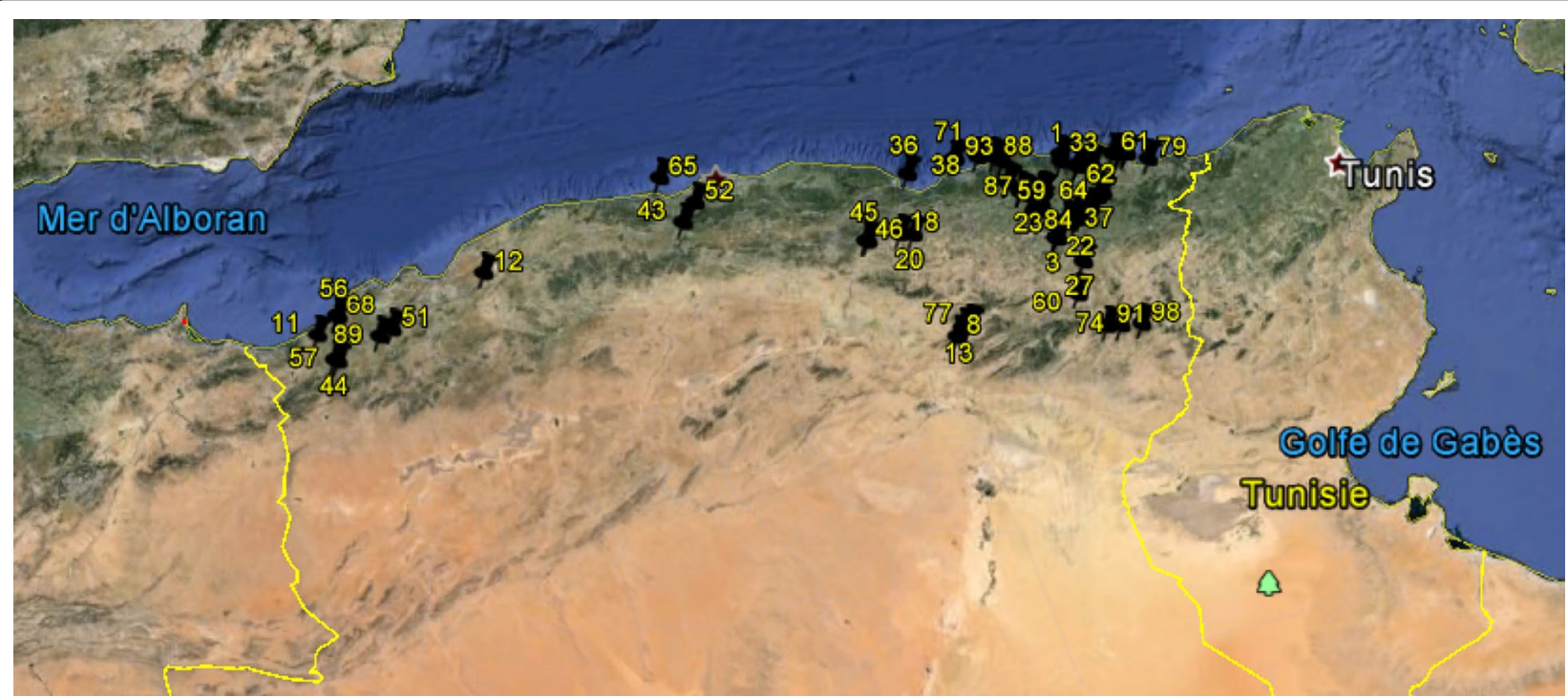

Fig. 1 Geographical origin of the 78 Algerian populations studied 
Table 1 Location and taxonomic identification of accessions investigated

\begin{tabular}{|c|c|c|c|c|c|c|}
\hline Species/subspecies & Code & $\begin{array}{l}\text { Date of collec- } \\
\text { tion }\end{array}$ & Province/locality/origin & Latitude & Longitude & Altitude (m) \\
\hline \multirow[t]{11}{*}{ V. sativa subsp. consobrina (Pomel) Maire } & 5 & 28.5.14 & Guelma & $\mathrm{N} 36^{\circ} 26.187^{\prime}$ & $\mathrm{E} 007^{\circ} 17.772^{\prime}$ & 339 \\
\hline & 14 & 1.6.14 & Annaba El bouni & N36 $49.777^{\prime}$ & $\mathrm{E} 007^{\circ} 38.290^{\prime}$ & 28 \\
\hline & 36 & 23.5.14 & Béjaia Affalou & $\mathrm{N} 36^{\circ} 40.381^{\prime}$ & $\mathrm{E} 005^{\circ} 08.903^{\prime}$ & 1 \\
\hline & 59 & 30.5 .14 & Jijel & N36 $35.082^{\prime}$ & E006 $16.728^{\prime}$ & 141 \\
\hline & 64 & 1.6 .14 & Skikda Azzaba & $\mathrm{N} 36^{\circ} 43.532^{\prime}$ & $\mathrm{E} 007^{\circ} 04.706^{\prime}$ & 111 \\
\hline & 86 & 13.6.14 & $\begin{array}{l}\text { Constantine Djbel El } \\
\text { Ouehch }\end{array}$ & $\mathrm{N} 36^{\circ} 23.690^{\prime}$ & $\mathrm{E} 006^{\circ} 39.011^{\prime}$ & 880 \\
\hline & $65 a$ & 9.6 .14 & $\begin{array}{l}\text { Tipaza El Beldj Chenoua } \\
\text { mountain }\end{array}$ & N36 $37.667^{\prime}$ & $\mathrm{E} 002^{\circ} 21.150^{\prime}$ & 345 \\
\hline & 52 & 4.6.14 & $\begin{array}{l}\text { Blida National parc of } \\
\text { Chréa }\end{array}$ & $\mathrm{N} 36^{\circ} 24.538^{\prime}$ & $E 002^{\circ} 45.519^{\prime}$ & 249 \\
\hline & 53 & 30.5.14 & Jijel & - & - & - \\
\hline & 85 & 1.6.14 & Skikda Ain Charchar & $\mathrm{N} 36^{\circ} 44.366^{\prime}$ & $\mathrm{E} 007^{\circ} 14.176^{\prime}$ & 52 \\
\hline & 93 & 30.5.14 & Jijel & $N 36^{\circ} 48.699^{\prime}$ & $\mathrm{E} 005^{\circ} 41.679^{\prime}$ & 25 \\
\hline \multirow[t]{16}{*}{ V. sativa subsp. obovata Gaudin } & 6 & 22.5 .14 & Constantine Chaab ersas & $N 36^{\circ} 20.628^{\prime}$ & E006 $37.485^{\prime}$ & 563 \\
\hline & 7 & 30.5 .14 & Mila Messaoud Boudjriou & $\mathrm{N} 36^{\circ} 29.743^{\prime}$ & $\mathrm{E} 006^{\circ} 25.527^{\prime}$ & 325 \\
\hline & 10 & 27.5.14 & $\begin{array}{l}\text { Constantine Didouche } \\
\text { Mourad }\end{array}$ & $\mathrm{N} 36^{\circ} 28.409^{\prime}$ & $\mathrm{E} 006^{\circ} 38.239^{\prime}$ & 468 \\
\hline & 17 & 22.5 .14 & Constantine Chaab ersas & $\mathrm{N} 36^{\circ} 20.628^{\prime}$ & E006 $37.485^{\prime}$ & 563 \\
\hline & 20 & 3.6.14 & Sétif Ain arnat & N36 $07.394^{\prime}$ & $\mathrm{E} 005^{\circ} 12.172^{\prime}$ & 866 \\
\hline & 22 & 2.6.14 & Oum El Bouaghi Sigus & $\mathrm{N} 36^{\circ} 04.485^{\prime}$ & $\mathrm{E} 006^{\circ} 48.867^{\prime}$ & 822 \\
\hline & 28 & 30.5 .14 & Jijel & N36 $35.094^{\prime}$ & E006ำ16.732' & 168 \\
\hline & 51 & 6.6 .14 & Sidi Bel Abbes & $\mathrm{N} 35^{\circ} 10.824^{\prime}$ & W000 $36.026^{\prime}$ & 490 \\
\hline & 32 & 22.5.14 & Constantine Chaab Ersas & $N 36^{\circ} 20.634^{\prime}$ & E006 $37.486^{\prime}$ & 562 \\
\hline & 57 & 6.6 .14 & Tlemcen Ain fezza & N34 $52.732^{\prime}$ & W00 $1^{\circ} 13.726^{\prime}$ & 867 \\
\hline & 61 & 1.6.14 & Annaba Berrahal & N36 $49.826^{\prime}$ & $\mathrm{E} 007^{\circ} 29.000^{\prime}$ & 38 \\
\hline & 68 & 6.6 .14 & Ain Temouchent & $\mathrm{N} 35^{\circ} 16.464^{\prime}$ & W001 ${ }^{\circ} 13.836^{\prime}$ & 281 \\
\hline & 72 & 28.5.14 & Constantine Ain abid & $\mathrm{N} 36^{\circ} 13.543^{\prime}$ & E006 $55.782^{\prime}$ & 847 \\
\hline & 80 & 28.5.14 & Constantine Ain abid & $\mathrm{N} 36^{\circ} 13.543^{\prime}$ & E006 $55.782^{\prime}$ & 847 \\
\hline & 70 & 28.5.15 & Guelma & N36 $14.816^{\prime}$ & $\mathrm{E} 007^{\circ} 03.045^{\prime}$ & 757 \\
\hline & 83 & 26.5.14 & Batna Ain Touta & $\mathrm{N} 35^{\circ} 17.632^{\prime}$ & $\mathrm{E} 005^{\circ} 49.035^{\prime}$ & 683 \\
\hline V. sativa subsp. angustifolia (L.) Gaudin & 19 & 18.5.14 & Constantine Chaab Ersas & $\mathrm{N} 36^{\circ} 20.634^{\prime}$ & E006 $37.486^{\prime}$ & 562 \\
\hline \multirow[t]{11}{*}{ V. sativa subsp. cordata (Will) Batt. } & 8 & 26.5.14 & Biskra El Kantra & $\mathrm{N} 35^{\circ} 11.517^{\prime}$ & $\mathrm{E} 005^{\circ} 40.673^{\prime}$ & 467 \\
\hline & 11 & 6.6 .14 & Tlemcen & $\mathrm{N} 35^{\circ} 05.699^{\prime}$ & W001 $26.612^{\prime}$ & 90 \\
\hline & 13 & 26.5.14 & $\begin{array}{l}\text { Biskra El Kantra Ain } \\
\text { Skhoun }\end{array}$ & N35ำ. $16.087^{\prime}$ & $\mathrm{E} 005^{\circ} 44.174^{\prime}$ & 584 \\
\hline & 15 & 1.6.14 & Annaba & N36 $49.980^{\prime}$ & E007ㅇ‥092' & 24 \\
\hline & 33 & 29.5.14 & Skikda El hadaik & N36 $49.894^{\prime}$ & E006 53.079' & 26 \\
\hline & 35 & 1.6 .14 & Annaba El bouni & N36 $49.777^{\prime}$ & $\mathrm{E} 007^{\circ} 38.290^{\prime}$ & 28 \\
\hline & 37 & 28.5.14 & Guelma & $\mathrm{N} 36^{\circ} 28.361^{\prime}$ & $\mathrm{E} 007^{\circ} 21.280^{\prime}$ & 223 \\
\hline & 38 & 10.5.14 & Jijel & $N 36^{\circ} 49.348^{\prime}$ & $\mathrm{E} 005^{\circ} 56.706^{\prime}$ & 14 \\
\hline & 42 & 28.5.14 & Constantine Ain Abid & $\mathrm{N} 36^{\circ} 13.543^{\prime}$ & E006 $55.782^{\prime}$ & 847 \\
\hline & 47 & 22.5 .14 & Constantine University & $\mathrm{N} 36^{\circ} 20.387^{\prime}$ & E006 $37.177^{\prime}$ & 604 \\
\hline & 71 & 30.5 .14 & Jijel & $\mathrm{N} 36^{\circ} 47.625^{\prime}$ & $\mathrm{E} 005^{\circ} 39.746^{\prime}$ & 17 \\
\hline \multicolumn{7}{|l|}{ V. lutea L. } \\
\hline \multirow[t]{3}{*}{ V. lutea subsp. vestita (Boiss.) Rouy. } & 1 & 28.5.14 & Skikda Ramdane Djamel & N36 $45.977^{\prime}$ & E006 $53.432^{\prime}$ & 42 \\
\hline & 4 & 22.5 .14 & Constantine University & N36 $20.387^{\prime}$ & E006 $37.177^{\prime}$ & 604 \\
\hline & 58 & 27.5.14 & $\begin{array}{l}\text { Constantine Didouche } \\
\text { Mourad }\end{array}$ & $\mathrm{N} 36^{\circ} 30.025^{\prime}$ & $\mathrm{E} 006^{\circ} 40.058^{\prime}$ & 448 \\
\hline
\end{tabular}


Table 1 continued

\begin{tabular}{|c|c|c|c|c|c|c|}
\hline Species/subspecies & Code & $\begin{array}{l}\text { Date of collec- } \\
\text { tion }\end{array}$ & Province/locality/origin & Latitude & Longitude & Altitude (m) \\
\hline \multirow[t]{12}{*}{ V. lutea subsp. eu-lutea Maire } & 62 & 1.6.14 & Skikda Azzaba & $\mathrm{N} 36^{\circ} 43.531^{\prime}$ & $\mathrm{E} 007^{\circ} 04.708^{\prime}$ & 110 \\
\hline & 63 & 1.6.14 & Skikda Ain Cherchar & $\mathrm{N} 36^{\circ} 44.366^{\prime}$ & $\mathrm{E} 007^{\circ} 14.176^{\prime}$ & 52 \\
\hline & 79 & 1.6.14 & El Tarf Ben M'hidi & $\mathrm{N} 36^{\circ} 46.402^{\prime}$ & $\mathrm{E} 007^{\circ} 53.600^{\prime}$ & 11 \\
\hline & 87 & 30.5 .14 & Jijel El Milia & $\mathrm{N} 36^{\circ} 46.668^{\prime}$ & $\mathrm{E} 006^{\circ} 13.551^{\prime}$ & 28 \\
\hline & 90 & 1st.6.14 & Annaba & $\mathrm{N} 36^{\circ} 49.980^{\prime}$ & $\mathrm{E} 007^{\circ} 34.092^{\prime}$ & 24 \\
\hline & 88 & 30.5 .14 & Jijel El Ansar & $\mathrm{N} 36^{\circ} 48.661^{\prime}$ & $\mathrm{E} 006^{\circ} 08.016^{\prime}$ & 30 \\
\hline & 3 & 2.6 .14 & Oum El Bouaghi Sigus & $N 36^{\circ} 04.485^{\prime}$ & $\mathrm{E} 006^{\circ} 48.867^{\prime}$ & 822 \\
\hline & 12 & 5.6.14 & Relizane & $\mathrm{N} 35^{\circ} 43.689^{\prime}$ & $\mathrm{E} 000^{\circ} 24.265^{\prime}$ & 105 \\
\hline & 26 & 28.5.15 & Guelma & $\mathrm{N} 36^{\circ} 14.816^{\prime}$ & $\mathrm{E} 007^{\circ} 03.045^{\prime}$ & 757 \\
\hline & 27 & 2.6 .14 & Oum El Bouaghi & $\mathrm{N} 35^{\circ} 51.459^{\prime}$ & $\mathrm{E} 007^{\circ} 06.377^{\prime}$ & 887 \\
\hline & 40 & 28.5.14 & Guelma & $N 36^{\circ} 16.276^{\prime}$ & $\mathrm{E} 007^{\circ} 05.751^{\prime}$ & 711 \\
\hline & 44 & 6.6 .14 & Tlemcen & 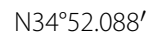 & W001⒒698' & 843 \\
\hline \multicolumn{7}{|l|}{ V. monantha Retz } \\
\hline \multirow[t]{12}{*}{ V. monantha subsp. calcarata (Desf.) Maire } & 45 & 3.6.14 & Bordj Bou Areridj & $\mathrm{N} 36^{\circ} 04.070^{\prime}$ & $\mathrm{E} 004^{\circ} 41.899^{\prime}$ & 923 \\
\hline & 49 & 28.5.14 & Constantine Ain Abid & N36ำ $13.543^{\prime}$ & E006 $55.782^{\prime}$ & 847 \\
\hline & 60 & 2.6 .14 & Khenchla & N35 $33.685^{\prime}$ & $\mathrm{E} 007^{\circ} 02.177^{\prime}$ & 860 \\
\hline & 74 & 14.6.14 & Tébessa & $\mathrm{N} 35^{\circ} 15.936^{\prime}$ & ${\mathrm{E} 007^{\circ} 30.306^{\prime}}^{\prime}$ & 1078 \\
\hline & 77 & 26.5.14 & Batna Ain Touta & $\mathrm{N} 35^{\circ} 17.632^{\prime}$ & $E 005^{\circ} 49.035^{\prime}$ & 683 \\
\hline & 78 & 20.5.14 & Constantine Coudiat & $\mathrm{N} 36^{\circ} 21.787^{\prime}$ & E006 $36.418^{\prime}$ & 633 \\
\hline & 84 & 10.6.14 & Constantine INATAA & N36ำ $19.002^{\prime}$ & $\mathrm{E} 006^{\circ} 34.626^{\prime}$ & 586 \\
\hline & 29 & 2.6 .14 & Oum El Bouaghi Sigus & $\mathrm{N} 36^{\circ} 04.485^{\prime}$ & $\mathrm{E} 006^{\circ} 48.867^{\prime}$ & 822 \\
\hline & 18 & 3.6.14 & $\begin{array}{l}\text { Bordj Bou Areridj Ain } \\
\text { taghrout }\end{array}$ & $\mathrm{N} 36^{\circ} 07.741^{\prime}$ & $\mathrm{E} 005^{\circ} 03.364^{\prime}$ & 934 \\
\hline & 98 & 14.6.14 & Tébessa Chria & $\mathrm{N} 35^{\circ} 16.328^{\prime}$ & $\mathrm{E} 007^{\circ} 44.359^{\prime}$ & 1087 \\
\hline & 102 & & Constantine University & $N 36^{\circ} 20.387^{\prime}$ & $\mathrm{E} 006^{\circ} 37.177^{\prime}$ & 604 \\
\hline & 43 & 4.6.14 & Médéa Oued Harbil & $N 36^{\circ} 13.633^{\prime}$ & $\mathrm{E} 002^{\circ} 37.643^{\prime}$ & 464 \\
\hline \multirow[t]{2}{*}{ V. monantha ssp. cinerea (M.B.) Maire } & 46 & 3.6.14 & Bordj Bou Areridj El Achir & $\mathrm{N} 36^{\circ} 04.017^{\prime}$ & $\mathrm{E} 004^{\circ} 40.525^{\prime}$ & 944 \\
\hline & 91 & 14.6.14 & Khenchla & $\mathrm{N} 35^{\circ} 15.704^{\prime}$ & $\mathrm{E} 007^{\circ} 20.957^{\prime}$ & 1222 \\
\hline \multicolumn{7}{|l|}{ V. narbonensis L. } \\
\hline \multirow[t]{7}{*}{-} & 23 & 30.5 .14 & $\begin{array}{l}\text { Constantine Hamma } \\
\text { Bouziane (Chaabet El } \\
\text { Medhbouh) }\end{array}$ & $N 36^{\circ} 26.391^{\prime}$ & $\mathrm{E} 006^{\circ} 33.282^{\prime}$ & 425 \\
\hline & 30 & 30.5 .14 & Mila Messaoud Boudjriou & $\mathrm{N} 36^{\circ} 29.748^{\prime}$ & $\mathrm{E} 006^{\circ} 25.530^{\prime}$ & 325 \\
\hline & 34 & 27.4.14 & $\begin{array}{l}\text { Constantine Didouche } \\
\text { Mourad }\end{array}$ & $N 36^{\circ} 29.216^{\prime}$ & $E 006^{\circ} 38.731^{\prime}$ & 434 \\
\hline & 41 & 28.5.14 & Guelma & 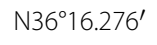 & $\mathrm{E} 007^{\circ} 05.751^{\prime}$ & 711 \\
\hline & 55 & 27.5 .14 & $\begin{array}{l}\text { Constantine Didouche } \\
\text { Mourad }\end{array}$ & N36 $30.023^{\prime}$ & $E 006^{\circ} 40.051^{\prime}$ & 443 \\
\hline & 66 & 28.5.14 & Guelma & N36º 19.930 & $\mathrm{E} 007^{\circ} 12.447^{\prime}$ & 698 \\
\hline & 81 & 22.5 .14 & Constantine University & $\mathrm{N} 36^{\circ} 20.387^{\prime}$ & E0063․ $37.177^{\prime}$ & 604 \\
\hline \multicolumn{7}{|l|}{ V. tenuifolia Roth. } \\
\hline \multirow[t]{2}{*}{-} & 56 & 6.6.14 & Ain Temouchent & $\mathrm{N} 35^{\circ} 16.476^{\prime}$ & W001 ${ }^{\circ} 13.800^{\prime}$ & 276 \\
\hline & 89 & 6.6 .14 & Sidi Bel Abbes Sidi Khaled & $\mathrm{N} 35^{\circ} 06.59^{\prime}$ & W000 $44.238^{\prime}$ & 543 \\
\hline \multicolumn{7}{|l|}{ V. leucantha Biv. } \\
\hline- & 100 & 10.6.14 & Constantine INATAA & N36 $19.002^{\prime}$ & $\mathrm{E} 006^{\circ} 34.626^{\prime}$ & 586 \\
\hline
\end{tabular}

\section{Electrophoresis}

Non-reducing SDS-PAGE was undertaken according to Laemmli (1970). Bromophenol blue was added to the extraction buffer to follow proteins movement in the gel. 15,8 and $70 \mu \mathrm{l}$ of respectively albumins, globulins and prolamins supernatants were placed on biphasic 
Table 2 Climatic characteristics of reference stations (2004-2014)

\begin{tabular}{|c|c|c|c|c|c|c|}
\hline Reference station & Latitude & Longitude & Alt. (m) & $P(m m)$ & $\mathrm{m}\left({ }^{\circ} \mathrm{C}\right)$ & $\mathrm{M}\left({ }^{\circ} \mathrm{C}\right)$ \\
\hline Jijel (airport) & $36^{\circ} 48 \mathrm{~N}$ & $05^{\circ} 53 \mathrm{E}$ & 8 & 1066.1 & 6.8 & 31.5 \\
\hline Skikda & $36^{\circ} 53 \mathrm{~N}$ & $06^{\circ} 54 \mathrm{E}$ & 2 & 829 & 8.8 & 29 \\
\hline Annaba & $36^{\circ} 50 \mathrm{~N}$ & $07^{\circ} 48 \mathrm{E}$ & 3 & 684.4 & 6.7 & 31.5 \\
\hline Béjaia & $36^{\circ} 43 \mathrm{~N}$ & $05^{\circ} 04 \mathrm{E}$ & 2 & 833 & 7.4 & 30.7 \\
\hline Constantine & $36^{\circ} 17 \mathrm{~N}$ & $06^{\circ} 37 \mathrm{E}$ & 693 & 486.6 & 2.2 & 35.2 \\
\hline Mila ${ }^{a}$ & $36^{\circ} 27 \mathrm{~N}$ & $06^{\circ} 16 \mathrm{E}$ & 437 & 742 & 4.4 & 31.5 \\
\hline Sétif (Ain Arnat) & $36^{\circ} 10 \mathrm{~N}$ & $05^{\circ} 19 \mathrm{E}$ & 1007 & 401.8 & -2 & 34.8 \\
\hline Oum El Bouaghi & $35^{\circ} 52 \mathrm{~N}$ & $07^{\circ} 07 \mathrm{E}$ & 889 & 410.4 & 1.1 & 35 \\
\hline Tlemcen (zenata) & $35^{\circ} 01 \mathrm{~N}$ & $01^{\circ} 28 \mathrm{~W}$ & 246 & 359.8 & 6.2 & 33.9 \\
\hline Ain Temouchent ${ }^{a}$ & $35^{\circ} 17 \mathrm{~N}$ & $01^{\circ} 08 \mathrm{~W}$ & 235 & 485 & 6.8 & 30.2 \\
\hline Biskra & $34^{\circ} 48 \mathrm{~N}$ & $05^{\circ} 44 \mathrm{E}$ & 82 & 143 & 6.9 & 41.3 \\
\hline Guelma & $36^{\circ} 28 \mathrm{~N}$ & $07^{\circ} 28 \mathrm{E}$ & 227 & 622.3 & 4.5 & 36.4 \\
\hline Sidi Bel Abbes & $35^{\circ} 12 \mathrm{~N}$ & $00^{\circ} 37 \mathrm{~W}$ & 475 & 375.1 & 2.8 & 36 \\
\hline Tipaza El Beldja & $36^{\circ} 38 \mathrm{~N}$ & $02^{\circ} 21 \mathrm{E}$ & 22 & 631 & 8.4 & 30.8 \\
\hline Blida $^{a}$ & $36^{\circ} 27 \mathrm{~N}$ & $02^{\circ} .44$ & 1458 & 916 & -0.9 & 28.5 \\
\hline Relizane & $35^{\circ} 44 \mathrm{~N}$ & $00^{\circ} 32 \mathrm{E}$ & 95 & 352.5 & 5.3 & 38.6 \\
\hline Bordj Bou Arerridj & $36^{\circ} 04 N$ & $04^{\circ} 46 \mathrm{E}$ & 928 & 392.9 & 1.7 & 36.4 \\
\hline Khenchla & $35^{\circ} 28 \mathrm{~N}$ & $07^{\circ} 05 \mathrm{E}$ & 983 & 520.8 & 1.8 & 34.9 \\
\hline Tébessa & $35^{\circ} 25 \mathrm{~N}$ & $08^{\circ} 07 \mathrm{E}$ & 821 & 382.6 & 1.7 & 35.6 \\
\hline Batna & $35^{\circ} 45 \mathrm{~N}$ & $06^{\circ} 19 \mathrm{E}$ & 822 & 346.8 & 0.1 & 36.4 \\
\hline Mila & $36^{\circ} 27 \mathrm{~N}$ & $06^{\circ} 16 \mathrm{E}$ & 437 & 742 & 4.4 & 31.5 \\
\hline Ain Temouchent ${ }^{\mathrm{a}}$ & $35^{\circ} 17 \mathrm{~N}$ & $01^{\circ} 08 \mathrm{~W}$ & 235 & 485 & 6.8 & 30.2 \\
\hline El Tarf Ben M'hidia & $36^{\circ} 46 \mathrm{~N}$ & $07^{\circ} 54 \mathrm{E}$ & 6 & 707 & 7.1 & 31.2 \\
\hline Médéa & $36^{\circ} 17 \mathrm{~N}$ & $02^{\circ} 44 \mathrm{E}$ & 1030 & 780 & 3.5 & 32.5 \\
\hline
\end{tabular}

Alt altitude, $P$ annual rainfall, $M$ and $m$ are the average maximum temperature of the hottest month and the average of the minimum of the coldest month, respectively

a Data from "http://climate-data.org"

polyacrylamide gels (12\%). $10 \mu \mathrm{l}$ of a protein molecular weight marker (BIO-RAD Precision Plus Protein Standards) containing ten proteins $(10,15,20,25,37,50,75$, 100,150 and $250 \mathrm{kDa}$ ) was used as standard. Tris-glycine ( $\mathrm{pH}$ 8.3) was used as electrode buffer. Runs were carried out at a voltage of $60 \mathrm{~V}$ and $500 \mathrm{~mA}$ overnight. Gels were stained by Coomassie Brilliant Blue R, then images were scanned using ImageScannerIII.

\section{Ecogeographic parameters of investigated sites}

The five ecological factors of Mediterranean climate (annual rainfall, average of the maximum temperature of the hottest month, average of a minimum temperature of the coldest month, Emberger coefficient and altitude) were used to characterize sampling stations. A global positioning systems (GPS GARMIN eTrex ${ }^{\circledR}$ model 30) was used to collect coordinates of sites investigated. Data recorded to ONM (National Office of Meteorology, Algeria) were used to characterize the climate of sites investigated (Table 2). Data recorded to CLIMATE-DATA.ORG (http://fr.climate-data.org/) were used for five stations (Mila, Ain Temouchent, Tipaza, El Tarf and Blida).

\section{Climatic data correction}

Correction of precipitations and temperatures data based on extrapolations for different altitudinal points were undertaken (Table 3), according to the works of Seltzer (1946) as explained by Bechkri and Khelifi (2016).

\section{Calculation of the bioclimatic coefficient of Emberger (1955) and definition of the bioclimate}

The pluviothermic Emberger quotient (Q2) is determined by three major climate factors. Stewart's formula (1969) was used in the present study. Details of calculations were reported by Bechkri and Khelifi (2016).

\section{Data analysis}

The mobility and the frontal report of each band were calculated. The size marker standard curve was traced. The graphical equation and the coefficient of determination 
Table 3 Corrected climatic data and Emberger quotient calculation of sampling sites of accessions studied

\begin{tabular}{|c|c|c|c|c|c|c|c|}
\hline Station code & Alt. (m) & $\mathrm{K}$ & $P(\mathrm{~mm})$ & $\mathrm{m}\left({ }^{\circ} \mathrm{C}\right)$ & $\mathrm{M}\left({ }^{\circ} \mathrm{C}\right)$ & Q2 & Bioclimate \\
\hline 5 & 339 & 1.0719 & 667.04 & 4.05 & 35.71 & 72.25 & SH-temperate winter \\
\hline 14 & 28 & 1.0292 & 704.38 & 6.6 & 31.32 & 97.71 & SH-mild winter \\
\hline 36 & 1 & 0.9990 & 832.16 & 7.40 & 30.70 & 122.48 & SH-warm winter \\
\hline 59 & 141 & 1.0998 & 1172.49 & 6.26 & 30.56 & 165.49 & LH-mild winter \\
\hline 64 & 111 & 1.1051 & 916.12 & 8.36 & 28.93 & 152.73 & LH-warm winter \\
\hline 86 & 880 & 1.1537 & 561.39 & 1.45 & 33.89 & 59.35 & HSA-cool winter \\
\hline $65 a$ & 345 & 1.4095 & 889.39 & 7.10 & 28.53 & 142.34 & LH-warm winter \\
\hline 52 & 249 & 0.4720 & 432.35 & 3.93 & 36.96 & 44.90 & MSA-temperate winter \\
\hline 93 & 25 & 1.0127 & 1079.63 & 6.73 & 31.38 & 150.23 & LH-mild winter \\
\hline 6 & 563 & 1.1068 & 538.56 & 2.72 & 36.11 & 55.32 & HSA-ool winter \\
\hline 7 & 325 & 0.9396 & 697.18 & 4.84 & 32.28 & 87.16 & SH-mild winter \\
\hline 10 & 468 & 0.8150 & 396.57 & 3.1 & 36.77 & 40.39 & MSA-temperate winter \\
\hline 17 & 563 & 1.1068 & 538.56 & 2.72 & 36.11 & 55.32 & HSA-cool winter \\
\hline 20 & 866 & 0.8596 & 345.38 & 1.43 & 35.78 & 34.48 & LSA-cool winter \\
\hline 22 & 822 & 0.9346 & 383.55 & 1.36 & 33.40 & 39.38 & MSA-cool winter \\
\hline 28 & 168 & 1.1200 & 1194.03 & 6.16 & 30.38 & 169.09 & LH-mild winter \\
\hline 32 & 562 & 1.1076 & 538.95 & 2.72 & 36.11 & 55.35 & HSA-cool winter \\
\hline 51 & 490 & 1.0159 & 381.06 & 2.74 & 35.89 & 39.42 & MSA-cool winter \\
\hline 57 & 867 & 1.6903 & 608.16 & 3.71 & 29.55 & 80.73 & SH-temperate winter \\
\hline 61 & 38 & 1.0409 & 712.39 & 6.56 & 31.25 & 98.94 & SH-cool winter \\
\hline 68 & 281 & 1.0379 & 503.38 & 6.61 & 29.87 & 74.22 & SH-mild winter \\
\hline 72 & 782 & 1.0731 & 522.17 & 1.84 & 34.57 & 54.71 & HSA-cool winter \\
\hline 80 & 782 & 1.0731 & 522.17 & 1.84 & 34.57 & 54.71 & HSA-cool winter \\
\hline 70 & 757 & 1.3406 & 834.25 & 0.79 & 32.79 & 89.42 & SH cold winter \\
\hline 83 & 683 & 0.8396 & 291.17 & 0.65 & 37.37 & 27.20 & HA-cold winter \\
\hline 19 & 562 & 1.1076 & 538.95 & 2.72 & 36.11 & 55.35 & HSA-cool winter \\
\hline 8 & 467 & 2.0769 & 296.99 & 5.36 & 38.60 & 30.64 & HA-mild winter \\
\hline 11 & 90 & 0.8265 & 297.37 & 6.82 & 34.99 & 36.21 & HA-mild winter \\
\hline 13 & 584 & 2.4041 & 343.78 & 4.89 & 37.78 & 35.84 & HA-mild winter \\
\hline 15 & 24 & 1.0245 & 701.16 & 6.61 & 31.35 & 97.22 & SH-mild winter \\
\hline 33 & 26 & 1.0231 & 848.14 & 8.70 & 29.53 & 139.67 & SH-warm winter \\
\hline 35 & 28 & 1.0292 & 704.38 & 6.6 & 31.32 & 97.71 & SH-mild winter \\
\hline 37 & 223 & 1.0025 & 611.62 & 4.51 & 36.52 & 65.53 & SA-mild winter \\
\hline 38 & 14 & 1.0045 & 1070.9 & 6.77 & 31.45 & 148.82 & LH-mild winter \\
\hline 42 & 847 & 1.1265 & 548.15 & 1.58 & 34.12 & 57.78 & HSA-cool winter \\
\hline 47 & 604 & 0.9268 & 450.98 & 2.55 & 35.82 & 46.49 & HSA-cool winter \\
\hline 71 & 17 & 1.0067 & 1108.4 & 6.76 & 31.43 & 154.13 & LH-mild winter \\
\hline 85 & 52 & 1.0482 & 868.95 & 8.6 & 28.65 & 148.65 & LH-warm winter \\
\hline 1 & 42 & 1.0386 & 860.99 & 8.64 & 28.72 & 147.07 & LH-warm winter \\
\hline 4 & 604 & 0.9268 & 450.98 & 2.55 & 35.82 & 46.49 & HSA-cool winter \\
\hline 58 & 448 & 0.7986 & 388.59 & 3.18 & 36.91 & 39.52 & MSA-temperate winter \\
\hline 62 & 110 & 1.1042 & 701.16 & 8.36 & 28.24 & 120.97 & SH-warm winter \\
\hline 63 & 52 & 1.0482 & 868.95 & 8.6 & 28.65 & 148.65 & LH-warm winter \\
\hline 79 & 11 & 1.0056 & 710.93 & 7.08 & 31.16 & 101.27 & SH-warm winter \\
\hline 87 & 28 & 1.0150 & 1082.09 & 6.72 & 31.36 & 150.63 & LH-mild winter \\
\hline 90 & 24 & 1.0245 & 701.16 & 6.61 & 31.35 & 97.21 & SH-mild winter \\
\hline 88 & 30 & 1.0165 & 1083.69 & 6.71 & 31.34 & 150.91 & LH-mild winter \\
\hline 3 & 822 & 0.9346 & 383.56 & 1.36 & 35.46 & 38.58 & MSA-cool winter \\
\hline 12 & 105 & 1.0113 & 356.48 & 5.26 & 38.53 & 36.75 & LSA-mild winter \\
\hline
\end{tabular}


Table 3 continued

\begin{tabular}{|c|c|c|c|c|c|c|c|}
\hline Station code & Alt. (m) & $\mathrm{K}$ & $P(m m)$ & $\mathrm{m}\left({ }^{\circ} \mathrm{C}\right)$ & $\mathrm{M}\left({ }^{\circ} \mathrm{C}\right)$ & Q2 & Bioclimate \\
\hline 26 & 755 & 1.3393 & 833.44 & 2.38 & 32.80 & 93.97 & SH-cool winter \\
\hline 27 & 887 & 0.9980 & 409.57 & 1.108 & 35.014 & 41.43 & MSA-cool winter \\
\hline 40 & 711 & 1.3111 & 815.89 & 2.56 & 32.80 & 92.54 & SH-cool winter \\
\hline 44 & 843 & 2.3274 & 837.39 & 3.81 & 29.72 & 110.85 & LH-temperate winter \\
\hline 45 & 923 & 0.9949 & 390.89 & 1.72 & 36.43 & 38.63 & MSA-cool winter \\
\hline 49 & 847 & 1.1265 & 548.15 & 1.58 & 34.12 & 57.78 & HSA-cool winter \\
\hline 60 & 860 & 0.9055 & 471.58 & 2.29 & 35.76 & 48.33 & HSA-cool winter \\
\hline 74 & 1078 & 1.2686 & 485.36 & 0.67 & 33.80 & 50.25 & HSA-cold winter \\
\hline 77 & 683 & 0.8396 & 291.17 & 0.65 & 37.37 & 27.20 & HA-cold winter \\
\hline 78 & 633 & 0.9506 & 462.56 & 2.44 & 35.62 & 47.82 & HSA-cool winter \\
\hline 84 & 586 & 0.9120 & 466.85 & 2.62 & 35.94 & 48.06 & HSA-cool winter \\
\hline 98 & 1087 & 1.2780 & 488.96 & 0.63 & 33.73 & 50.67 & HSA-cold winter \\
\hline 102 & 604 & 0.9268 & 450.98 & 2.55 & 35.82 & 46.49 & HSA-cool winter \\
\hline 43 & 464 & 0.7097 & 553.56 & 5.76 & 36.46 & 77.08 & SH-mild winter \\
\hline 29 & 822 & 0.9346 & 383.56 & 1.36 & 35.46 & 38.58 & MSA-cool winter \\
\hline 18 & 934 & 1.0061 & 395.29 & 1.67 & 36.35 & 39.10 & MSA-cool winter \\
\hline 46 & 944 & 1.0162 & 399.26 & 1.63 & 36.28 & 39.52 & MSA-cool winter \\
\hline 91 & 1222 & 1.1835 & 616.36 & 0.84 & 33.22 & 65.29 & SH-cold winter \\
\hline 23 & 425 & 0.7796 & 379.35 & 2.62 & 35.94 & 39.05 & MSA-cool winter \\
\hline 30 & 325 & 0.9396 & 697.18 & 4.84 & 32.28 & 87.15 & SH-mild winter \\
\hline 34 & 434 & 0.7870 & 382.95 & 3.23 & 37.01 & 38.88 & MSA-temperate winter \\
\hline 41 & 711 & 1.3111 & 815.89 & 2.56 & 33.12 & 91.58 & SH-cool winter \\
\hline 55 & 443 & 0.7944 & 386.55 & 3.2 & 36.95 & 39.28 & MSA-temperate winter \\
\hline 66 & 698 & 1.4 & 871.22 & 2.61 & 33.20 & 97.68 & SH-cool winter \\
\hline 81 & 604 & 0.9268 & 450.98 & 2.55 & 35.82 & 46.49 & HSA-cool winter \\
\hline 56 & 276 & 1.0338 & 501.38 & 6.63 & 29.91 & 73.87 & SH-mild winter \\
\hline 89 & 543 & 1.0725 & 402.29 & 2.52 & 35.52 & 41.81 & MSA-cool winter \\
\hline 100 & 586 & 0.912 & 466.85 & 2.62 & 35.94 & 48.06 & HSA-cool winter \\
\hline
\end{tabular}

$K$ correction factor, $A$ lt altitude, $P$ annual rainfall, $M$ and $m$ the average maximum temperature of the hottest month and the average of the minimum of the coldest month, respectively, Q2 Emberger coefficient, SH subhumid, LH less humid, HSA higher semiarid, HA higher arid, MSA means semiarid, LSA less semiarid, SA semiarid

allowed the calculation of the molecular weight of each band. In this method, "absence" contributed equally to "presence" in the calculation of dissimilarity. Present bands were scored 1 and absent bands were scored 0 . For each fraction, a binary matrix was constructed. A dendrogram was produced by the UPGMA based on Jaccard index $(\mathrm{J})$ between protein patterns. Analyses were carried out using XLSTAT (Pearson edition, version 2014.5.03). For ecogeographic parameters, Euclidean distances (Romesburg 1990) were used in the estimation of the genetic resemblance. Matrix including the five ecological parameters of each accession was used to elaborate a dendrogram using UPGMA. Analyses were carried out with STATISTICA (version 6.1 program). The possible correlation between albumins, globulins and prolamins patterns, was evaluated by a Mantel test (Mantel 1967) based on Pearson's correlation (XLSTAT Pearson edition, version 2014.5.03). The same test was used to test geographical matrix with seed albumins, globulins and prolamins matrices.

\section{Results}

Seed proteins variability

The three fractions electrophoregrams are represented by some accessions illustrated in Fig. 2. Figure 3 presents dendrograms generated using UPGMA and Jaccard's index.

\section{Albumins patterns}

A total of 131 bands were detected with molecular weights ranged from 3.23 to $148.17 \mathrm{kDa}$. Each profile presents between 11 and 26 bands. All samples had more than one seed protein pattern. Intra-accessional diversity was also investigated by examining populations of the same taxa. The largest number of bands (25) is obtained in $V$. monantha subsp. calcarata, $V$. tenuifolia 


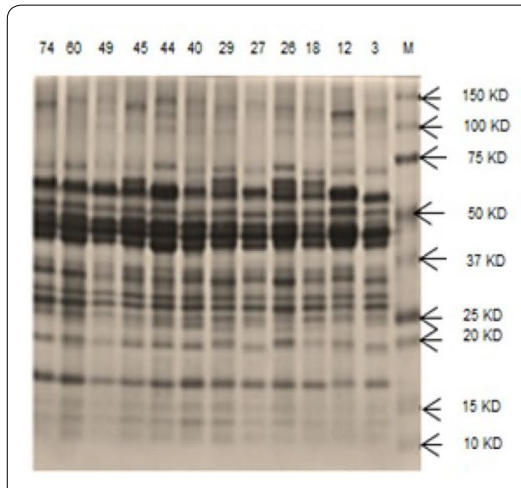

$\mathbf{a}$
$\begin{array}{lllllllllllll}M & 3 & 12 & 18 & 28 & 27 & 29 & 40 & 44 & 45 & 49 & 80 & 74\end{array}$

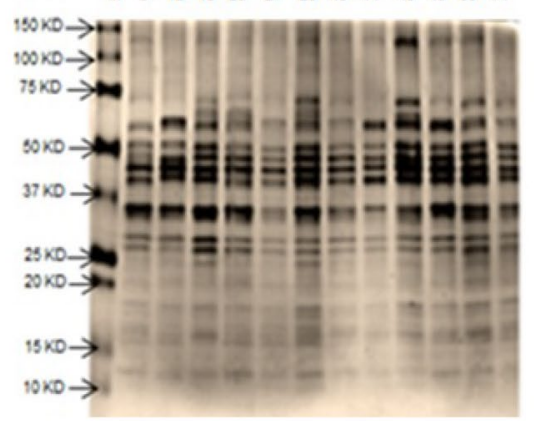

b

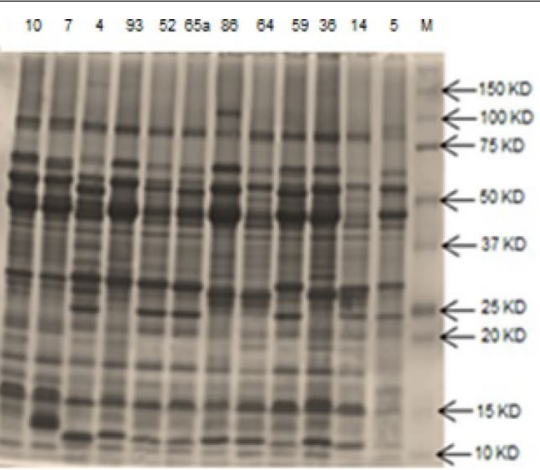

c

Fig. 2 Electrophoretic banding pattern generated by SDS-PAGE of seed storage proteins of some Vicia accessions studied. M marker, a globulins, b prolamins, c albumins

and $V$. sativa subsp. obovata. The lowest number (11) is obtained in $V$. lutea subsp. vestita. The band $37.73 \mathrm{kDa}$ is the most common as it appears in 48 profiles followed by the band $9.19 \mathrm{kDa}$ appeared in 43 profiles and the band $24.22 \mathrm{kDa}$ observed in 40 profiles. In parallel, bands 3.23 , 9.46, 15.81, 19.80, 24.87, 25.97, 46.86, 63.69, 66.34, 76.29, $99.86,113.50$ and $125.98 \mathrm{kDa}$ are the least common as they are specific for one accession and appear each in 1 profile, followed by bands $8.85,14.93,16.72,42.84,75.43$, $77.31,82.63$ and $88.47 \mathrm{kDa}$ appeared each in two profiles. The cluster analysis indicated the discrimination into five groups at 0.86 Jaccard distance (Fig. 3). The first cluster can be divided into two groups, the first one includes accessions 12, 3, 27, 18, 26. The second one regroups samples $1,58,63,87,4,90,62$ and 79 . The cluster II is divided into 2 sub-clusters. The first one contains samples $5,6,59,14,52,65,36,93,7,10,64$ and 86 . The second one can further be divided into two groups: II2a contains accessions $34,41,55,30$ and 81 . II2b is composed of samples $32,66,68,57,61$. The cluster III regroups two sub-clusters. The first one contains accessions $33,35,11$, $37,83,42,38$. The second one is further divided into two groups: III2a comprises sample 88 linked to $40,29,102$, $49,77,45,60,74,78,44$ and 91 . III2b contains accessions $17,28,51,20,22,23$ and 84 . The cluster IV comprises the sample 100 one side and accessions $72,56,70,46,43$, 53, 71, 89, 19 and 80 another side. Finally, the cluster V contains the sample $98(\mathrm{~J}=0.88)$. The proximity matrix using Jaccard index shows that the higher distance $(J=1)$ is observed between the following couples: 17-4, 1-30, 1-32, 1-37, 1-41, 1-81, 4-28, 4-32, 4-84, 6-63, 6-87, 7-87, 63-10, 87-10, 14-63, 14-87, 17-63, 28-63, 30-58, 32-58, 62-32, 79-32, 32-90, 37-90, 58-37, 37-62, 41-58, 41-1, 52-87, 55-1, 55-58, 58-81, 66-58, 58-41, 58-30, 58-32, 59-63, 87-59, 63-93, 63-84, 63-7, 63-23, 63-52, 63-64, 63-65, 64-87, 65-87, 1-66, 79-32, 87-93, 87-65. The lower distance $(\mathrm{J}=0.10)$ is obtained between 18 and 26 . A distance of 0.16 is observed between 43 and 19. Between 89 and 19, a distance of $J=0.15$ is observed. A distance of 0.17 is obtained between 90 and 62 .

\section{Globulin patterns}

A total of 119 bands were obtained with molecular weights ranged from 2.77 to $131.88 \mathrm{kDa}$. Each profile presents between 6 and 27 bands. Two accessions (41 and 55) showed a unique protein pattern; the remaining accessions had more than one protein pattern. The largest number of bands (27) is observed for accessions 43 (V. monantha subsp. calcarta) and 87 (V. lutea subsp. eu-lutea). The lowest number (6) is obtained for samples 17 and 32 belonging to $V$. sativa subsp. obovata. The band $35.53 \mathrm{kDa}$ is the most common as it appears in 52 profiles, followed by the band $49.45 \mathrm{kDa}$ observed in 45 profiles and the band $33.44 \mathrm{kDa}$ found in 37 profiles. In another side, bands 5.10, 5.46, 51.74, 67.97, 78.27, 85.47, 95.33, 100.77, 103.66, 104.69, 115.04, 119.96, $130.35 \mathrm{kDa}$ are the less common as they appear each in one profile, followed by bands 16.86, 18.39, 19.11, 28.98, 37.69, 47, $38.87,68.53,86.70$ and $131.88 \mathrm{kDa}$ found in two profiles. Six major clusters were obtained at the distance of 0.87 (Fig. 3b). The cluster I is further divided into two subclusters (I1, I2). I1 includes the accession 46 linked to $62,63,90,79,88,4,87,1$ and 58 . I2 can be divided into two groups. The first one (I2a) includes $59,52,65,86,64$, 36,14 and 93 . The second one (I2b) contains samples 6 , 7 and 10. The cluster II is divided into two subclusters (II1, II2). II1 comprises two groups. II1a contains accessions $55,41,30,81,34,23$. II1b is composed of 35,15 , $13,8,33,85,83,42,11,37,47,38$. II2 comprises sample 12 linked to $49,60,45,74,18,29,26,40,44,3$ and 27. Cluster III contains sample 43 linked to accessions 68,80 , $5,72,19$ and 61 . The cluster IV $(J=0.92)$ comprises samples $32,17,28,22,20,51$ and 57 . The cluster $\mathrm{V}(\mathrm{J}=0.87)$ is divided into two sub-clusters. V1 includes 70, 56, 100, 

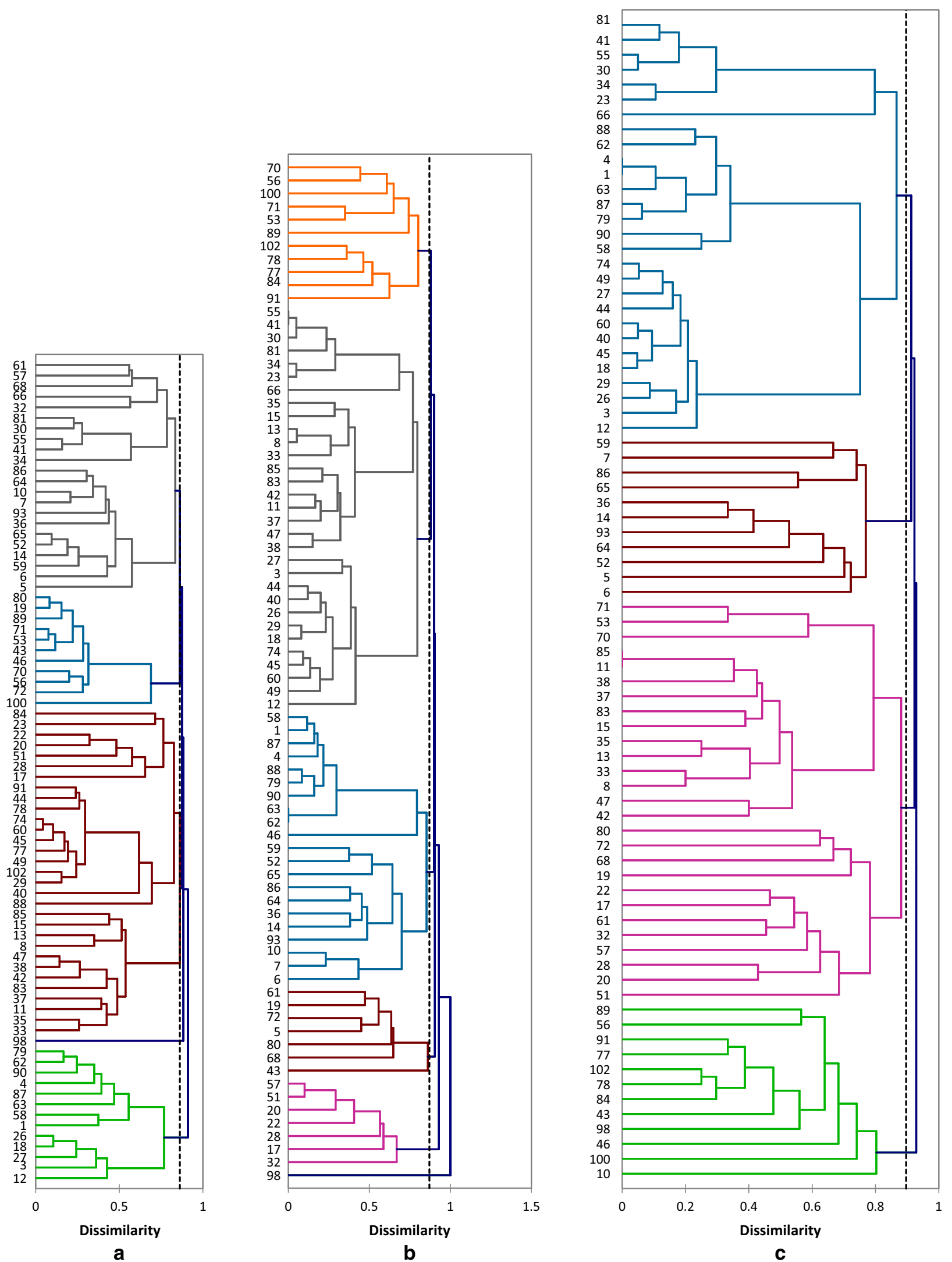

Fig. 3 Dendrograms generated using UPGMA cluster analysis and Jaccard's index based on seed proteins diversity of 78 Vicia accessions. a Albumins, b globulins, c prolamins 
71, 53 and 89. V2 contains samples 102, 78, 77, 84 and 91. The accession 98, being itself the cluster VI at $J=1$. The dissimilarity matrix shows that a distance of 0.00 is observed between couples: 62-63, 55-41. A low distance of 0.11 is observed between samples 1 and 58 . Between accessions 1 and 4 , a distance of 0.14 is observed. Samples 58 and 4 are distant by $J=0.18$. A distance of 0.14 is obtained between 1 and 87 . Samples 4 and 88 have a distance of 0.15 . The higher distance $(J=1)$ is observed between 98 and all other accessions. The same distance is observed for the following couples: 5-66, 5-34, 5-22, 5-23, 10-20, 10-22, 72-17, 68-17, 46-17, 43-17, 19-17, 81-19, 84-19, 66-19, 65-19, 55-19, 57-19, 51-19, 41-19, 32-19, $34-19,23-19,20-52,22-80,22-72,22-68,22-62,22-63$, $22-52,22-46,22-28,22-19,19-30,32-43,32-46,32-68$, $32-71,46-51,46-57,51-68,51-72,57-72,93-61,100-65$, 93-80, 98-100 and 98-102.

\section{Prolamin patterns}

A total of 98 bands were obtained with molecular weights ranged from 11.36 to $137.638 \mathrm{kDa}$. Each profile presents between 6 and 24 bands. Two accessions ( 1 and 4) showed a single protein pattern; the remaining accessions had more than one seed protein pattern. The largest number of bands (24) is observed in patterns 58 ( $V$. lutea subsp. vestita) and 62 ( $V$. lutea subsp. eulutea). The lowest number (6) is obtained for samples 19 (V. sativa subsp. angustifolia), 7 and 51 both belonging to $V$. sativa subsp. obovata. The band $17.65 \mathrm{kDa}$ is the most common as it appears in 46 profiles followed by the band $41.49 \mathrm{kDa}$ appeared in 39 profiles and the band $35.53 \mathrm{kDa}$ observed in 29 profiles. Bands 12.44, $51.51,53,56.62,78.57,83.92,89.03,94.53,104.51$, $105.45,115.08,118.17$ and $137.63 \mathrm{kDa}$ are the less common as they appear in one profile each, followed by bands 29.49, 66.63, 68.33, 81.77, 85.10, 106.71, 109.03 and $127.97 \mathrm{kDa}$ obtained each in two profiles. The UPGMA generated four major clusters at the distance of $J=0.89$. The first cluster (I) is divided into two subclusters (I1, I2). I1 includes samples $81,41,55,30,34$, 23 and 66. I2 can further be divided into two groups (I2a, I2b). I2a contains accessions 88, 62, 4, 1, 63, 87, 79, 90 and 58. I2b is composed of 74, 49, 27, 44, 60, $40,45,18,29,26,3$ and 12 . The cluster II comprises two sub-clusters (II1, II2). II1 contains accessions 59, 7, 86, 65. II2 includes 36, 14, 93, 64, 52, 5 and 6. The cluster III $(J=0.92)$ comprises two sub-clusters (III1, III2). III1 is composed of accessions 71, 53 and 70 in the group III1a and accessions 85, 11, 38, 37, 83, 15, 35, $13,33,8,47$ and 42 in the group III1b. The sub-cluster III2 includes two groups. III2a contains accessions 80 , 72, 68 and 19. III $2 \mathrm{~b}$ is composed of 22, 17, 61, 32, 57,
28, 20 and 51. The cluster IV includes samples 89,56 , $91,77,102,78,84,43,98,46,100$ and 10 . The proximity matrix using Jaccard's index shows that a distance of $\mathrm{J}=0$ is observed between samples 1 and 4 . The same distance is obtained between accessions 11 and 85 . Between accessions 40 and 60 , a distance of 0.05 can be observed. A distance of 0.08 is obtained between samples 26 and 29. A low distance of 0.10 can be observed for the couples: 1-63, 4-63, 23-34, 55-81, 60-74. Between samples 3 and 29, 63 and 87, a distance of $J=0.16$ is observed. Samples 41 and 81, 63 and 79 are distant by 0.11 . A distance of 0.17 is obtained for: $3-26$, 26-18, 49-29. Samples 49 and 12 are distant by $J=0.19$. A distance of 0.18 is observed between accessions 12 and 26 and accessions 26 and 49. Accessions 26-27, 26-74 and 45-49 are distant by $J=0.14$. A distance of 0.15 is observed for accessions 27-49 and 30-81. Couples 29-60 and 29-45 have a distance of 0.13. The higher distance $(J=1)$ is obtained for a large number of couples as for: 1-84, 1-100, 3-65, 3-59, 3-32, 3-28, 3-20, 4-84, 4-100, 5-100, 5-80, 5-72, 5-68, 5-61, 5-57, 5-51, $5-43,5-34,5-32,5-28,5-23,5-19,5-20,5-22,5-17$, 6-43, 6-102, 7-102, 7-100, 7-91, 7-84, 7-77, 7-78, 7-66, $7-61,7-46,7-51,7-43,7-32,7-33,7-28,7-20,7-22$, $7-17,7-13,7-8,8-19,8-43,8-46,8-56,8-59,8-65,8-77$, 8-78, 8-84, 8-86, 8-91, 8-98, 8-100, 8-102, 10-61, 10-57, 10-32, 10-28, 10-20, 11-19, 11-43, 11-46, 11-56, 11-59, $11-65,11-77,11-78,11-84,11-86,11-91,11-98,11-100$, $11-102,12-65,12-61,12-59,12-51,12-32,12-28,12-19$, $12-20,13-19,13-46,13-56,13-59,13-65,13-77,13-98$, 13-100, 13-72, 13-68, 13-61, 13-46, 13-51, 13-43, 13-32, $13-28,13-20,13-22,13-17,15-59,15-65,15-86,17-86$, $17-64,17-65,17-59,17-52,17-36,18-20,18-28,18-32$, $18-51,18-59,18-61$.

\section{Mantel test}

A Mantel test based on Pearson's correlation was used to highlight correlations between the matrices of albumins (matrix A), globulins (matrix B) and prolamins (matrix C). The $p$ value was calculated from the distribution of $\mathrm{r}(\mathrm{AB})$ using 10,000 permutations with the value of $r(A B . C)=0.3099$. This test showed significant correlation between the three fractions studied since the calculated $p$-value $(<0.0001)$ is below the significance level of alpha $(0.05=5 \%)$. Concerning the correlation between ecogeography and seed proteins, $r$ values were -0.0012 , -0.0039 and 0.0166 respectively for albumins, globulins and prolamins. $p$-values are $0.8233,0.9319$ and 0.3689 respectively for the three fractions. Thus, Mantel test showed no significant correlation between ecogeography and protein patterns since the calculated $p$-values are below the significance level of alpha. 


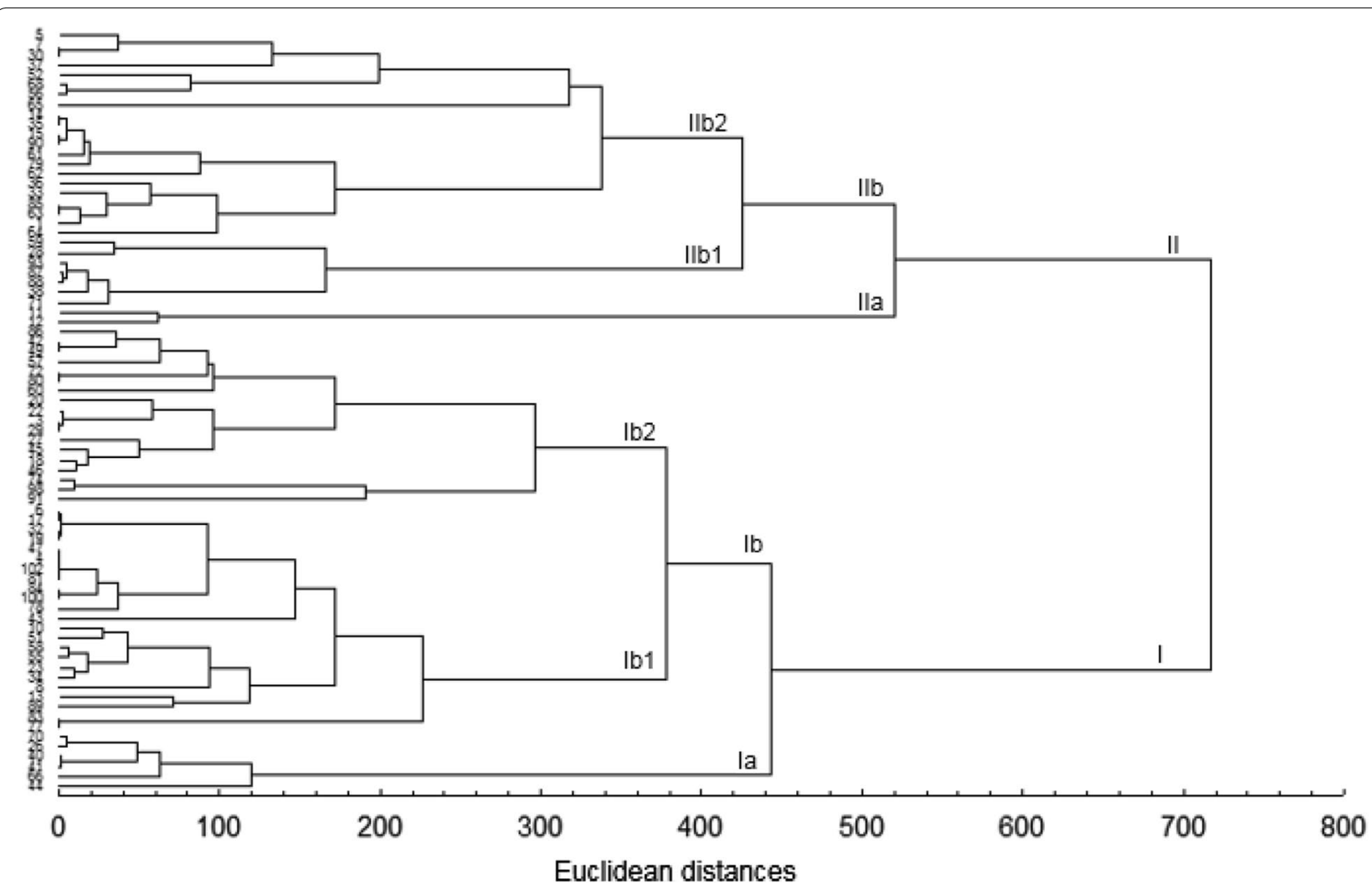

Fig. 4 Dendrogram generated using UPGMA cluster analysis and Euclidean distances based on ecogeographic characterization of sites investigated

\section{Cluster analysis based on ecogeographic data}

The dendrogram illustrated in Fig. 4 shows the relationships between these taxa, based on the variation in the five ecogeographic parameters studied. At the Euclidean distance of 716.43 , the dendrogram can be divided into two major clusters (I and II). The first one is further divided into two sub-clusters (Ia and Ib). Ia ( $\mathrm{d}=119.65)$ comprises samples 44, 66, 41, 40, 26 and 70 belonging to 2 bioclimates (LH-SH). Ib can be divided into Ib1 $(\mathrm{d}=226.96)$ and Ib2 (295.93). Ib1 contains the sample 77 (HA) linked to accessions $83,89,13,8,34,23$, $55,58,51,10,43,78,100,84,81,102,4,47,19,32,17$ and 6 from 4 bioclimates (HA-MSA-SH-HSA). Ib2 $(\mathrm{d}=295.93)$ is composed of samples $91,98,74$ belonging to 2 bioclimates (SH-HSA) linked to 46, 18, 45, 27, 29, 3 (MSA) then 22, 20, 60, 80, 72, 57, 49, 42 and 86. (MSA-LSA-HSA-SH). The second cluster comprises subclusters IIa which contains samples 12 (LSA) and 11 (HA) and IIb. The latter comprises groups IIb1 $(\mathrm{d}=165.56)$ composed of accessions $71,38,88,87,93$, 28 and 59 belonging to 1 bioclimate (LH) and IIb2 which can further be divided into two groups: At a distance of $\mathrm{d}=172.22$, the first group contains accessions 64 , $1,63,85,33,36,62,79,61,90,15,35$ and 14 collected from two bioclimates ( $\mathrm{LH}-\mathrm{SH})$. The second group $(d=317.53)$ comprises sample $65(\mathrm{LH})$ linked to accessions $56,68,52,37,30,7$ and 5 (SH-MSA-SA). The higher distance $(\mathrm{d}=1286)$ is observed between 91 ( $V$. monantha subsp. cinerea, $\mathrm{SH}$ ) and 93 ( $V$. sativa subsp. consobrina, $\mathrm{LH})$. A distance of $\mathrm{d}=1284$ is obtained between 87 ( $V$. lutea subsp. eu-lutea, LH) and 91. The distance of $\mathrm{d}=0$ is obtained between the following couples: 35-14, 6-17, 32-19, 80-72, 15-90, 42-49, 47-4, 47-102, 47-81, 85-63, 4-102, 77-83, 102-81, 3-29, 30-7, 100-84 and 4-81. Low distances of $\mathrm{d}=1$ are observed between 6 and 19, 17 and 19, 41 and 40 .

\section{Discussion}

The discrimination in the genus Vicia into subgenera, sections and subsections was undertaken by several studies, based on morphological and cytological analyses (Hanelt and Mettin 1989; Kupicha 1976; Leht 2009). In the present work, seed storage proteins and ecogeographic parameters were used. 


\section{Seed proteins variability}

The differences among accessions were observed and all eleven taxa can be recognized by their protein profiles. Samples within each taxon showed a different number of bands with different molecular weights. Thus, intraspecific heterogeneity is obtained. A positive correlation was exhibited between seed globulin, seed albumin and seed prolamin contents (highly significant). Our results partially confirmed classification of Vicia by Kupicha (1976), Hanelt and Mettin (1989) and Leht (2009) at subgeneric and sectional levels. According to Osborne (1924), proteins are classified into albumins, globulins, prolamins and glutelins based on their solubility which is a convenient method to initiate the discrimination of the seed storage proteins from a species that has not been studied in detail (Ribeiro et al. 2004). The differences in the three fractions profiles of individual seeds was expected since Mudzana et al. (1995) and Goodrich et al. (1985) found that there was variability in the total seed storage protein profiles of individual seeds within a subspecies. This was probably due the cross fertilization nature of the genus.

\section{Albumins patterns}

Albumins cluster analysis revealed five major clusters, differing only in the relative position of some accessions in subgroups. Populations of $V$. monantha subsp. calcarata belonging to section Cracca of the subgenus Vicilla (sensu Kupicha) are linked to samples of V. lutea (Sect. Hypechusa) which indicates a close relationship between the two subspecies of $V$. lutea when it is difficult to determine distinct groups which could be individually identified as eu-lutea or as vestita. There are bands which are specific of some accessions and can be used as markers to discriminate samples at interspecific level. Discrimination at intraspecific level is also obtained by albumins patterns. The use of albumins proved to be helpful in revealing interspecific variability and intraspecific diversity in the studied taxa. Some bands are specific constant markers for each taxon and can be discriminated bay their electrophoregrams. Other bands are common of several taxa. Albumins present the highest bands number which indicates major role of albumin heterogeneity in discriminating the Vicia samples (Mustafa 2007).

\section{Globulins patterns}

Cluster analysis of globulins patterns revealed six basic groups. A low distance can be observed between samples of $V$. lutea subsp. vestita or by samples of $V$. lutea subsp. eu-utea and V. lutea subsp. vestita. V. narbonensis (sect. Narbonensis) and $V$. lutea subsp. vestita (sect. Hypechusa) present close globulin profiles. These results concord with those of Jaaska (1997), Jaaska and Leht (2007) and Shiran and Raina (2014), which showed the species of sections Hypechusa as sister to the clade of section Narbonensis. High distances are observed between $V$. narbonensis (sect. Narbonensis) and $V$. sativa (sect. Vicia) and between species of $V$. sativa or between $V$. lutea subsp. eu-lutea (sect. Hypechusa) and V. sativa. Globulins are the major storage proteins present in seeds of legumes (Freitas et al. 2000) and differences both at intraspecific and interspecific levels can be obtained by globulins patterns. A good example in this case is the one of sample 43 ( $V$. monantha subsp. calcarata) characterized by 3 specific bands (51.74, 78.27 and $115.04 \mathrm{kDa})$. The unique population of $V$. leucantha also has a specific band (119.96 kDa). Samples of V. monantha subsp. calcarata are a good example for intraspecific heterogeneity as shown by accessions 102 and 43, characterized by one specific band each.

\section{Prolamins patterns}

Cluster analysis of prolamins patterns revealed four basic groups. Few studies have been reported concerning the utilization of prolamins patterns to discriminate Vicia taxa in comparison with albumins and globulins. The classification obtained using the UPGMA showed that samples belonging to the same taxon close together in the clusters. A common profile was observed for samples 1 and 4 belonging to $V$. lutea subsp. vestita, but this taxon also showed other patterns. It is may be due to the fact that native wild populations are composed of a mixture of genotypes which provide survival advantages in varied environmental conditions. Outcrossing could also be an explanation of diversity in the accessions studied, as indicated for several types of vetch (Hanelt and Mettin 1989; Mirali et al. 2007). The sample 10 ( $V$. sativa subsp. obovata) showed differences in its electrophoregram compared to the other taxon members, and might be considered an "off type" as proposed by De la Rosa and Gonzalez (2010). Prolamins patterns are a good discriminatory marker in Vicia taxa at both intraspecific and interspecific levels especially for $V$. sativa samples as the subspecies belonging to this species can be characterized by specific bands as in the case of samples $6,10,57,82$ and 95 of $V$. sativa subsp. obovata or samples 48, 77 and 42 belonging to $V$. sativa subsp. cordata. V. leucantha, $V$. tenuifolia and $V$. narbonensis are also characterized by specific bands which could be considered as markers at interspecific level.

\section{Interspecific and intraspecific variation V. sativa s.l. (Sect. Vicia)}

Vicia sativa is the most polymorphic species of the genus Vicia and the debate about its taxonomic classification is extensive. In the present work, the all studied taxa of $V$. sativa s.l (section Vicia) are found in the same group on 
the basis of albumins homology and can be found in three clusters which indicates a close relationship between subspecies of $V$. sativa when it is difficult to observe separate groups which could be identified as obovata, consobrina, cordata or angustifolia. In our previous paper using plant morphology (Bechkri and Khelifi 2016), our results have demonstrated that in the $V$. sativa using morphological traits alone do not provide a stable grouping. A close relationship between samples can be seen. The picture generated between the phylogenetic trees may be due to the possible phylogenetic instability of these taxa as indicated by Leht (2009).

\section{V. narbonensis (Sect. Narbonensis) and V. lutea (Sect. Hypechusa)}

On the basis of albumins patterns, all populations of $V$. narbonensis belong to the same subcluster except for the accession 23 which is linked to accessions of $V$. sativa. Globulins patterns linked all accessions of $V$. narbonensis together. Accessions of $V$. narbonensis clustered together using prolamins profiles. Albumins, globulins and prolamins patterns joined all samples of $V$. lutea in the same subcluster with no discrimination between subsp. eulutea and subsp. vetsita. These observations show that there is an overlap between accessions of these two subspecies. The utilization of seed storage proteins shows a close relationship between the taxa when it is difficult to distinguish groups which could be identified as eu-lutea or as vestita. Albumins and globulins profiles not link accessions of $V$. lutea and $V$. narbonensis. Prolamins patterns of the present study concord with those of Jaaska (1997) and Jaaska and Leht (2007) and Shiran and Raina (2014) which showed the species of sections Hypechusa as sister to the clade of section Narbonensis. Our data revealed that subgenus Vicia is a well-separated subgenus and agreed with the results based on morphology reported by Diklic (1972) and with results on phylogenetic relationships (Potokina et al. 1999; Leht 2009). Seed albumins, globulins and prolamins patterns showed $V$. lutea samples to form an homogenous group. The same findings were reported by Przybylska and ZimniakPrzybylska (1997).

\section{V. monantha, V. tenuifolia and V. leucantha (Section Cracca)}

Samples of $V$. monantha clustered together in two different groups on the basis of albumins patterns with no distinction between the two subspecies calcarata and cinerea. An exception is observed for two samples (43 and 46) which clustered with accessions of V. sativa, $V$. tenuifolia and $V$. leucantha. Globulins patterns joined the majority of samples of $V$. monantha subsp. calcarata all together with an exception for the sample 98 which forms a separate cluster. Profiles of $V$. monantha subsp. cinerea do not have provided clear groupings. Prolamins patterns gave stable groups where samples of subsp. monantha are linked together. Six samples clustered together in another subcluster which contains samples of subsp. cinerea. Samples of these species clustered together on the basis of albumins, globulins and prolamins patterns. They are also linked to samples of $V$. monantha. Thus, species of section Cracca sensu Kupicha belong to one group. Populations of $V$. tenuifolia, $V$. leucantha and $V$. monantha clustered together showing also an overlap between these taxa. These species are classified by Kupicha (1976) in the sub-genus Vicilla, section Cracca. Thus, the three species attributed to the section Cracca are joined in a separate group in the present work. V. tenuifolia and V. leucantha, are grouped in one subcluster of closely related taxa that provided strong homologous variation with shared characters. As a consequence, the treatment of $V$. tenuifolia, $V$. monantha and $V$. leucantha in the section Cracca is supported. In the present analysis, $V$. leucantha, the species transferred by Ball (1968) to his section Ervum, is in the same clade with the remaining Cracca species. In spite of this, our analysis of seed proteins supports Kupicha's placement of $V$. leucantha in section Cracca as was also done by Davis and Plitmann (1970).

\section{Ecogeographic characterization}

As the first step towards more efficient conservation is to undertake an ecogeographic study (Maxted et al. 1996), the aim of the present work was to collect ecogeographic informations from investigated stations of Vicia L. Analysis of the passport data will elucidate each taxon's geographic and ecological location. The distribution maps will be used in the planning of future collecting missions. The wide geographic ranges may explain the high degree of protein seed storage variation among accessions and should be considered in conservation programs of this Vicia taxa (El Bakatoushi and Ashour 2009). The obtained intraspecific diversity within the taxa reflects a wide geographical and ecological distribution of this species as reported by Ehrman and Maxted (1990) and Maxted (1995). Studying the species from different geographic regions and altitudes, indicates that the species may be still evolving in different pathways as reported by Ashour et al. (2005). According to Hannelt and Mettin (1989), Vicia taxa do not tolerate extreme environmental conditions. Whereas, Francis et al. (2000) report that $V$. sativa has good adaption to adverse environmental conditions. Cluster analysis shows that samples having differences in electropherograms and belonging to different taxa can belong to an identical bioclimate and altitudes as in the case of accessions 19 and 32 which were collected from the same locality. In parallel, there are samples with high protein homology level which are collected from 
stations belonging to the same bioclimate. Accessions 72 and 80 are a good example in this case. The dendrogram obtained with ecogeographic parameters did not indicate clear discrimination among accessions based on their geographical locations. The Mantel test between proteins patterns and ecogeography indicated that the correlation between proteins profiles resemblance and geographical origin is less significant. The same findings were reported by Chung et al. (2013), Potokina et al. (2003), Mirali et al. (2007) and De la Rosa and Gonzalez (2010). Considering all stations of the current paper, the studied samples of Vicia L. occur from 1 to $1222 \mathrm{~m}$. Stations belong to seven different bioclimates ( $\mathrm{SH}, \mathrm{LH}, \mathrm{HSA}, \mathrm{MSA}, \mathrm{LSA}, \mathrm{HA})$ and are characterized by cool, wild, warm or temperate winters. Considering all stations of the current work, $V$. sativa L. occurs from sea level to $880 \mathrm{~m}$ which is consistent with the findings of Maxted (1995). Samples of $V$. narbonensis were collected from sites receiving between 382.95 and $697.18 \mathrm{~mm}$ of precipitations and belonging to bioclimates characterized by cool or mild winter. Bennett and Maxted (1997) reported that the V. narbonensis occur over a wide range of altitudes, from sea level to $3200 \mathrm{~m}$ when Abd El Moneim (1992) reported that $V$. narbonensis adapts in areas receiving 250-300 $\mathrm{mm}$ annual precipitations and are characterized by low winter temperatures. Accessions of $V$. lutea were collected from sites belonging to four bioclimates (LH, HSA, MSA, SH) and altitudes ranged between 11 and $604 \mathrm{~m}$ with a minimum temperatures ranged from 2.55 to $8.64{ }^{\circ} \mathrm{C}$. Accessions 74, 77, 91 and 98 belonging to $V$. monanatha occur until $1222 \mathrm{~m}$ and at these altitudes, they require some frost tolerance as the temperatures can drop to $0.63{ }^{\circ} \mathrm{C}$ as in the case of the accession 98. V. leucantha was collected from a site characterized by HSA bioclimate with a minimum temperature of $2.62{ }^{\circ} \mathrm{C}$ (cool winter) and an altitude of $586 \mathrm{~m}$. The two samples of $V$. tenuifolia occurred in SH and MSA bioclimates with mild or cool winters and at altitudes of 276 and $543 \mathrm{~m}$. These patterns are not necessarily a real picture of the preferred altitude of these two taxa. A larger number of accessions from each geographical location should be tested to confirm patterns.

\section{Conclusion}

The electrophoregrams obtained can be exploited as passport data for the genetic diversity of the studied taxa. Seed protein electrophoresis is a valid tool for taxa discrimination. The variability observed indicates that improvement by simple selection for these traits is possible. No significant correlation is obtained between seed proteins and ecogeography. The use of more samples from different origins is necessary to include most of the genetic determinants of these traits.

\section{Authors' contributions}

All authors of the manuscript have read and agreed to its content and are accountable for all aspects of the accuracy and integrity of the manuscript in accordance with ICMJE criteria. All authors read and approved the final manuscript.

\section{Acknowledgements}

Not applicable.

Competing interests

The authors declare that they have no competing interests.

\section{Availability of data and materials}

Plant material is available in "laboratoire de génétique biochimie et biotechnologies végétales". Université Frères MENTOURI Constantine Algeria.

Consent for publication

Authors agree to the terms of the Springer Open Copyright and License Agreement.

Ethics approval and consent to participate

Authors agree to the terms of ethics approval and consent to participate.

\section{Funding}

This research did not receive any specific Grant from funding agencies in the public, commercial, or not-for-profit sectors.

\section{Publisher's Note}

Springer Nature remains neutral with regard to jurisdictional claims in published maps and institutional affiliations.

Received: 21 February 2017 Accepted: 12 May 2017

Published online: 21 June 2017

\section{References}

Abd El Moneim AM (1992) Narbon Vetch (Vicia narbonensis L.): a potential feed legume crop for dry areas in West Asia. J Agron Crop Sci 169(5):347-353

Ashour FM, El-Sadek LM, El-Badan GE (2005) Karyotypic relatedness among Vicia species. Egypt J Genet Cytol 34:345-353

Ball PW (1968) Vicia L. In: Tutin TG, Heywood VH, Burges NA, Moore DM, Valentine DH, Walters SM, Webb DA (eds) Flora Europaea, vol 2. Rosaceae to Umbelliferae. Cambridge University Press, Cambridge, pp 129-136

Bechkri S, Khelifi D (2016) Variation in Vicia sativa s.l. from Algeria based on morphological characters and ecogeographic parameters. Genet Resour Crop Evol. doi:10.1007/s10722-016-0404-1

Bennett SJ, Maxted N (1997) An ecogeographic analysis of the Vicia narbonensis complex. Genet Resour Crop Evol 44:411-428

Chung JW, Kim TS, Suresh S, Lee SY, Cho GT (2013) Development of 65 novel polymorphic CDNA-SSR markers in common vetch (Vicia sativa subsp sativa). Molecules 18(7):8376-8392

Crawford DJ (1990) Plant molecular systematics. Wiley, New York

Darre MJ, Minior DN, Tatake JG, Ressler C (1998) Nutritional evaluation of detoxified and raw common vetch seed using diets of broilers. J Agric Food Chem 46:4675-4679

Davis PH, Plitmann U (1970) Vicia L. In: Davis PH (ed) Flora of Turkey and the East Aegean Islands. University Press, Edinburgh, pp 274-321

De la Rosa L, Gonzalez JM (2010) The genetic diversity associated with seed proteins in a collection of Spanish underground vetches (Vicia sativa $\mathrm{L}$. subsp. amphicarpa (Dorthes) Asch. et Graebn.). Genet Resour Crop Evol 57:565-573

Diklic N (1972) Vicia L. In: Josifovic M (ed) Flora SR Srbije. Beograd, Sanu, pp 315-355

Ehrman TA, Maxted N (1990) Ecogeographic survey and collection of Syrian Vicieae and Cicereae (Leguminosae). Plant Genet Res Newsl 77:1-8 
El Bakatoushi R, Ashour FM (2009) Genetic diversity among some Vicia narbonensis L. varieties as revealed by karyotype and protein analysis. Egypt J Genet Cytol 38:85-97

Emberger L (1955) Une classification biogéographique des climats. Rec Trav Lab Bot Géol Fac Sci 7:1-43

Emre I, Turgut-Balik D, Genç H, Sahin A (2010) Total seed storage protein patterns of some Lathyrus species growing in Turkey using SDS-PAGE. Pak J Bot 42(5):3157-3163

Francis GM, Enneking D, Abd El Moneim AM (2000) When and where will vetches have an impact as grain legumes? In: Knight $R$ (ed) Linih'ng research and marketing opportunities for pulses in the 21st century. Proceedings of the Third International Food Legume Research Conference, Adelaide 1997. Current plant science and biotechnology in agriculture. Kluwer, London, p 375-384

Freitas RL, Ferreira RB, Teixeira AR (2000) Use of a single method in the extraction of the seed storage globulins from several legume species. Application to analyse structural comparisons within the major classes of globulins. Int J Food Sci Nutr 51:341-352

Goodrich W, Cooke J, Morgan AG (1985) The application of electrophoresis to the characterization of cultivars of Vicia faba L. FABIS News 13:8-11

Haider AS, El-Shanshoury AR (2000) Variability of storage proteins and esterase isozymes in Vicia sativa subsp. Biol Plant 43:205-209

Hameed A, Shah TM, Atta BM, lqbal N, Haq MA, Ali H (2009) Comparative seed storage protein profiling of Kabuli chickpea genotypes. Pak J Bot 41(2):703-710

Hanelt P, Mettin D (1989) Biosystematics of the genus Vicia L. (Leguminosae). Annu Rev Ecol Syst 20:199-223

Higgins TJV (1984) Synthesis and regulation of major proteins in seeds. Ann Rev Plant Physiol 35:191-221

Jaaska V (1997) Isoenzyme diversity and phylogenetic affinities in Vicia subgenus Vicia (Fabaceae). Genet Resour Crop Evol 44:557-574

Jaaska V, Leht M (2007) Phylogenetic relationships between and within sections Hypechusa, Narbonensis and Peregrinae of genus Vicia (Fabaceae) based on evidence from isozymes and morphology. CEJB 2(1):137-155

Kupicha FK (1976) The infrageneric structure of Vicia. Notes R Bot Gard Edinb 34:287-326

Ladizinsky G, Hymowitz T (1979) Seed protein electrophoresis in taxonomic and evolutionary studies: review. Theor Appl Genet 54:145-151

Laemmli UK (1970) Cleavage of structural proteins during the assembly of head of bacteriophage T4. Nature 227:680-685

Leht M (2009) Phylogenetics of Vicia (Fabaceae) based on morphological data. Feddes Repert 120(7-8):379-393

Mantel N (1967) Adaptation of Karber's method for estimating the exponential parameter from quantal data, and its relationship to birth, death, and branching processes. Biometrics 23:739-746
Maxted N (1993) A phenetic investigation of Vicia L. subgenus Vicia (Leguminosae, Vicieae). Bot J Linn Soc 111:155-182

Maxted N (1995) An ecogeographical study of Vicia subgenus Vicia. Systematic and ecogeographic studies on crop genepools 8. International Plant Genetic Resources Institute, Rome

Maxted N, Ford-Lloyd BV, Hawkes JG (1996) Complementary conservation strategies. In: Maxted N, Ford-Lloyd BV, Hawkes JG (eds) Plant genetic conservation: the in situ approach. Chapman and Hall, London, pp 20-57

Mirali N, El-Khouri S, Rizq F (2007) Genetic diversity and relationships in some Vicia species as determined by SDS-PAGE of seed proteins. Biol Plant 51(4):660-666

Mudzana G, Pickett AA, Jarman RJ, Cooke RT, Keefe PD (1995) Variety discrimination in faba beans (Vicia faba L.) an integrated approach. Plant Var Seeds 8:135-145

Mustafa AEZ (2007) Genetic variation among Egyptian cultivars of Vicia faba L. Pak J Biol Sci 10(23):4204-4210

Nemecek T, Von Richthofen JS, Dubois G, Casta P, Charles R, Pahl H (2008) Environmental impacts of introducing grain legumes into European crop rotations. Eur J Agron 28:380-393

Osborne TB (1924) The vegetable proteins. London, Longmans-Green

Potokina E, Tomooka N, Vaughan DA, Alexandrova T, Xu RQ (1999) Phylogeny of Vicia subgenus Vicia (Fabaceae) based on analysis of RAPDs and RFLP of PCR-amplified chloroplast genes. Genet Res Crop Evol 46:149-161

Potokina E, Endo Y, Eggi E, Ohashi H (2003) Electrophoretic patterns of seed proteins in the East Asian Vicia species (Leguminosae) and their systematic utility. J Japanese Bot 78(1):29-37

Przybylska J, Zimniak-Przybylska Z (1997) Electrophoretic seed albumin patterns in Vicia species of sectt. Hypechusa and Peregrinae (Fabaceae). Plant Syst Evol 208:239-248

Quézel P, Santa S (1962) Nouvelle flore de l'Algérie et des régions méridionales. Tome 1. Editions du centre national de la recherche scientifique, Paris, pp $524-531$

Ribeiro AC, Teixeira AR, Ferreira RB (2004) Characterization of globulins from common vetch (Vicia sativa L.). J Agric Food Chem 52:4913-4920

Romesburg HC (1990) Cluster analysis for researchers. Robert E. Krieger Publishing Company, Malabar

Seltzer P (1946) Le climat de I'Algérie. Alger, Carbonel, p 219

Shiran B, Raina SN (2014) Evidence of rapid evolution and incipient speciation in Vicia sativa species complex based on nuclear and organellar RFLPs and PCR analysis. Genet Resour Crop Evol 48:519-532

Stewart P (1969) Un nouveau climagramme pour l'Algérie et son application au barrage vert. Bull Soc Hist Nat Afr Nord 65:1-2

\section{Submit your manuscript to a SpringerOpen ${ }^{\odot}$ journal and benefit from:}

- Convenient online submission

- Rigorous peer review

- Open access: articles freely available online

- High visibility within the field

- Retaining the copyright to your article

Submit your next manuscript at $\boldsymbol{\nabla}$ springeropen.com 